\title{
Asthma Symptoms, Lung Function, and Markers of Oxidative Stress and Inflammation in Children Exposed to Oil Refinery Pollution
}

\author{
Franca Rusconi, M.D., ${ }^{1, *}$ Dolores Catelan, Ph.D., ${ }^{2,3}$ Gabriele Accetta, Ph.D., ${ }^{2}$ Marco \\ Peluso, M.SC., ${ }^{2}$ RicCardo Pistelli, M.D., ${ }^{4}$ Fabio Barbone, M.D.,${ }^{5}$ Eliana Di Felice, M.SC., ${ }^{6}$ \\ Armelle Munnia, M.SC., ${ }^{2}$ PaOlo Murgia, M.D. ${ }^{7}$ LuCiana Paladini, M.D.,${ }^{4}$ \\ Alessandro SERCI, M.SC., ${ }^{8}$ AND ANNiBAlE Biggeri, M.D. ${ }^{2,3}$ \\ ${ }^{1}$ Unit of Epidemiology, "Anna Meyer" Children's University Hospital, Florence, Italy. \\ ${ }^{2}$ ISPO Cancer Prevention and Research Institute, Florence, Italy. \\ ${ }^{3}$ Department of Statistics "G. Parenti," University of Florence, Florence, Italy. \\ ${ }^{4}$ School of Respiratory Medicine, Sacro Cuore University, Rome, Italy. \\ ${ }^{5}$ Institutes of Hygiene and Epidemiology, DPMSC, University of Udine, Udine, Italy. \\ ${ }^{6}$ Municipality of Sarroch, Sarroch, Italy. \\ ${ }^{7}$ Pneumology Unit, Local Health Unit, Carbonia, Italy. \\ ${ }^{8}$ Environmental Protection Agency of Sardinia, Sassari, Italy.
}

\begin{abstract}
Objectives. Little is known about the effects of exposure to petroleum refinery emissions on respiratory health in children. We evaluated lung function and markers of inflammation and oxidative stress in children and adolescents with and without asthma or wheezing symptoms living in a petrochemical polluted area (Sarroch, Sardinia) versus a reference area (Burcei). Methods. Parents of 275/300 6- to 14-year-old children living in Sarroch and parents of 214/323 children living in Burcei answered a questionnaire on respiratory symptoms and risk factors. Measurements of forced expiratory volume after 1 second $\left(\mathrm{FEV}_{1}\right)$ and of forced expiratory flow rates at $25-75 \%$ of vital capacity $\left(\mathrm{FEF}_{25-75}\right)$ were available in 27 and 23 asthma/wheezing-positive subjects and in 7 and 54 asthma/wheezing-negative subjects in Sarroch and in Burcei, respectively; for fractional exhaled nitric oxide $\left(\mathrm{FE}_{\mathrm{NO}}\right)$ corresponding figures were 27 and 24 and 8 and 55 in Sarroch and in Burcei, respectively. Malondialdehyde-deoxyguanosine (MDA-dG) adduct levels in nasal mucosa were measured in 12- to 14-year-old adolescents (8 and 14 asthma/wheezing-positive and 20 and 28 asthma/wheezing-negative subjects in Sarroch and in Burcei, respectively). Air pollutants were assessed during 3 weeks, starting 1 week before lung function, $\mathrm{FE}_{\mathrm{NO}}$, and MDA-dG measurements. Generalized linear models were used to estimate the effect of the area of residence adjusting for confounders. Results. Weekly average concentrations of sulfur dioxide were $6.9-61.6 \mu \mathrm{g} / \mathrm{m}^{3}$ in Sarroch versus $0.3-7.6 \mu \mathrm{g} / \mathrm{m}^{3}$ in the rural area of Burcei; of nitrogen dioxide, $5.2-28.7 \mu \mathrm{g} / \mathrm{m}^{3}$ versus $1.7-5.3 \mu \mathrm{g} / \mathrm{m}^{3}$; and of benzene, $1.8-9.0 \mu \mathrm{g} / \mathrm{m}^{3}$ versus $1.3-1.5 \mu \mathrm{g} / \mathrm{m}^{3}$, respectively. Children living in Sarroch versus children living in the reference area showed an increase in wheezing symptoms $\{$ adjusted prevalence ratio $=1.70[90 \%$ confidence interval $(\mathrm{CI})=1.01 ; 2.86]$; ; a decrease in lung function [variation in $\mathrm{FEV}_{1}=-10.3 \%(90 \% \mathrm{CI}=-15.0 ;-6.0 \%)$ and in $\mathrm{FEF}_{25-75}=-12.9 \%(90 \% \mathrm{CI}=-20.7 ;-4.3 \%)$ ]; an increase in bronchial inflammation [variation in $\mathrm{FE}_{\mathrm{NO}}=+35 \%(90 \% \mathrm{CI}=11.7 ; 80.1 \%)$ ]; and an increase in $\mathrm{MDA}-\mathrm{dG}$ adducts of $+83 \%(90 \% \mathrm{CI}=22.9 ; 174.1 \%)$. Conclusions. Data from this small study are consistent with the role of environmental pollutants on lung function and inflammation.
\end{abstract}

Keywords air pollution, biomarkers, malondialdehyde, nitric oxide, wheezing

\section{INTRODUCTION}

A number of cross-sectional and longitudinal studies performed in different countries have assessed the respiratory morbidity in children chronically exposed to air pollution; most of the data have been recently reviewed by Götschi et al. (1), concluding for adverse long-term effects on lung function. A plausible mechanism is airways inflammation that has been demonstrated in adults who live in a polluted area (2) and is thought to be mediated by oxidative stress defined as "a disturbance in the prooxidant-antioxidant balance in favor of the former, leading to potential damage" (3). Gaseous pollutants and particulate matter, in fact, form reactive oxygen species that react with proteins,

\footnotetext{
*Corresponding author: Franca Rusconi, M.D., Unit of Epidemiology, "Anna Meyer" Children's University Hospital, Viale Pieraccini 24, 50139 Florence, Italy; Tel: +39 055 5662556; Fax: +39 055 5662334; E-mail: f.rusconi@meyer.it
}

lipids, and DNA and form distinct products that can be used as biomarkers (4).

One of the most validated noninvasive tests available to assess lung inflammation is the determination of nitric oxide (NO), a reactive, free radical gas, which is formed in the airways when L-arginine is oxidized to L-citrulline. In addition to the potential clinical use of the measurement of fractional exhaled $\mathrm{NO}\left(\mathrm{FE}_{\mathrm{NO}}\right)$ in asthma management (5), $\mathrm{FE}_{\mathrm{NO}}$ has been suggested to be an effective noninvasive tool for epidemiological studies on health effect of air pollution (6).

More recently, malondialdehyde (MDA) levels measured in the exhaled breath condensate of children with asthma have also been associated with exposure to trafficrelated air pollutants (7). MDA is a lipid peroxidation product whose physiological endogenous production can be increased when oxygen radicals are not neutralized by the antioxidant defenses. MDA is a highly reactive 
substance that can react with DNA forming exocyclic DNA adducts, including MDA-deoxyguanosine (MDA$\mathrm{dG}$ ) adducts (8). MDA-dG adducts have been shown to be premutagenic in mammalian cells and to induce frameshift and base pair substitution mutations (9).

Sarroch (Sardinia, Italy) is a small municipality of 5243 inhabitants close to one of the biggest highcomplexity refinery in the Mediterranean Sea and to the largest European liquid fuel gasification plant. In 2005 according to the local air quality monitoring network (10), sulfur dioxide $\left(\mathrm{SO}_{2}\right)$ levels exceeded the hourly limit of $350 \mu \mathrm{g} / \mathrm{m}^{3}$ set by the Italian law (DM 60, 2 April 2002) 126 times. Particulate matter less than $10 \mu \mathrm{m}\left(\mathrm{PM}_{10}\right)$ in size exceeded the daily limit of $50 \mu \mathrm{g} / \mathrm{m}^{3} 15$ times. In the same year, a survey [DRIAS (Disturbi Respiratori nell'Infanzia e Ambiente in Sardegna)] investigated the respiratory health of children living in the southwest of Sardinia (11). The DRIAS study used a modified version of ISAAC (International Study of Asthma and Allergies in Childhood) questionnaire (12) and found an excess of respiratory symptoms, in particular wheezing symptoms, in 6- to 10-year-old children living in Sarroch (Biggeri A, unpublished data).

To evaluate the role of air pollution on lung function, oxidative stress, and inflammation, in May 2007 we conducted a cross-sectional survey in the municipality of Sarroch and in a nearby municipality (Burcei, 2978 inhabitants).

\section{Methods}

\section{Study Participants}

In December 2006, the parents of 6- to 14-year-old children and adolescents attending primary and middle schools in the municipality of Sarroch (300 subjects) were asked to complete a modified ISAAC questionnaire at home. The proportion of compliers was $91.7 \%$. A panel of 54 children and adolescents consented to participate in a longitudinal survey (January-June 2007) aimed at studying the lung function and $\mathrm{FE}_{\mathrm{NO}}$ in relation to air pollution. The panel study consisted of 27 of 37 subjects with a history of lifetime asthma or wheezing symptoms in the last 12 months, 19 of 34 subjects with a history of dry cough apart from cold or other respiratory symptoms apart from wheezing, and 8 subjects with no history of asthma, wheezing, or other symptoms suggestive of asthma (dry cough apart from cold, chest tightness) or bronchodilators use, randomly chosen in the same classes where asthmatic children were from. The 27 children with asthma/wheezing and the 8 subjects without asthma/wheezing also took part in this study on lung function and $\mathrm{FE}_{\mathrm{NO}}$ measurements in the last week of May 2007. In May 2007, the parents of 323 children and adolescents attending primary and middle schools in the nearby rural municipality of Burcei were also asked to complete the modified ISAAC questionnaire; parents of 214 subjects $(66.3 \%)$ consented. Twenty-four of the 35 children with a history of lifetime asthma or wheezing symptoms in the last 12 months and 55 children with no history of asthma/wheezing or other symptoms possibly suggestive of asthma or bronchodilators use, randomly selected from the same classes, consented to perform lung function and $\mathrm{FE}_{\mathrm{NO}}$ measurements in the last week of May.

In addition, according to a separate protocol, and after parental/child consent, measurements of nasal mucosal samples for MDA-dG adducts were obtained in the same week in 12- to 14-year-old adolescents. In both municipalities, we invited all asthma/wheezing-positive adolescents who had responded to the questionnaire, whereas a random sample of asthma/wheezing-negative adolescents was obtained from the same school classes. Eight asthma/wheezing-positive and 20 asthma/wheezingnegative adolescents in Sarroch and 14 asthma/wheezingpositive and 28 asthma/wheezing-negative adolescents in Burcei provided adequate biological samples for the measurements of MDA-dG adducts.

\section{Study Procedures}

Questionnaires. Data collection was performed using ISAAC questionnaire (12); for individual and family characteristics, occurrence of respiratory symptoms other than asthma, and children's exposure to known or suspected risk factors, we added specific questions derived from the SIDRIA (Studi Italiani sui Disturbi Respiratori nell'Infanzia e l'Ambiente) questionnaire (13). The questionnaire was completed by parents at home. A selfadministered questionnaire, mainly regarding personal smoking habits, was completed by adolescents (12-14 years old) at school.

$F E_{N O}$ and Lung Function Measurements. Subjects were examined in the morning at school. Height and body weight were measured, and each subject answered simple questions on the symptoms possibly related to recent respiratory infections. $\mathrm{FE}_{\mathrm{NO}}$ was measured online by chemiluminescence using the NIOX analyzer (Aerocrine, Stockholm, Sweden) and the following recommended procedures (14). Lung function tests were performed according to the American Thoracic Society guidelines (15) with a portable spirometer (Biomedin, Padua, Italy). The following variables were obtained from the best of three reproducible forced expiratory maneuvers: forced vital capacity (FVC), forced expiratory volume after 1 second $\left(\mathrm{FEV}_{1}\right)$, and forced expiratory rates at $25-75 \%$ of vital capacity $\left(\mathrm{FEF}_{25-75}\right)$.

MDA-dG Adducts. Cells from nasal mucosa were obtained by gentle brushing with a Pap test cytobrush after having washed the nasal cavity with saline solution $(0.9 \% \mathrm{NaCl})$ and cleaning it with a cotton swab. Cells were rinsed from the cytobrush into a tube containing $0.9 \%$ saline solution and $10 \%$ acetylcysteine, incubated for 30 minutes at room temperature, and centrifuged (100 cycles/min shaking frequency). The cell pellets were frozen shortly after collection and kept at $-80^{\circ} \mathrm{C}$ until DNA extraction. The analysis of MDA-dG adducts was carried out by the ${ }^{32} \mathrm{P}$-postlabeling DNA adduct assay, as previously described (16). MDA-dG 
adduct levels were expressed as relative adduct labeling (RAL) (screen pixel in adducted nucleotides/screen pixels in total nucleotides).

The protocol of this study was approved by the Ethics Committee of the Local Health Authority of Cagliari, and parents provided written consent for their child's participation.

\section{Pollutants Assessment}

Information on air quality was collected from 15 May (1 week before children examinations) to 7 June. Weekly average concentrations of $\mathrm{SO}_{2}$, nitrogen dioxide $\left(\mathrm{NO}_{2}\right)$, and benzene were assessed by passive dosimeters located on a regular grid of 21 locations in the municipality of Sarroch and at the primary and middle schools in Burcei. Weekly average concentrations of ozone were also assessed in the two municipalities by passive dosimeters, one in Sarroch and two in Burcei. The dosimeters are in accordance with the European Committee for Standardisation (17) and were analyzed by the Passam Ltd. (Männedorf, Switzerland). Temperature, relative humidity, and $\mathrm{PM}_{10}$ concentrations were measured by the Environmental Protection Agency Air Monitoring Network with two fixed monitoring stations and two mobile stations located at the middle school in Sarroch and at the primary school in Burcei. Daily averages were obtained following the Meta-analysis of the Italian Studies on Short-term effects of Air pollution (MISA) protocol (18).

\section{Statistical Analyses}

Four primary outcomes were studied: wheezing symptoms, lung function indexes $\left(\mathrm{FEV}_{1}\right.$ and $\left.\mathrm{FEF}_{25-75}\right), \mathrm{FE}_{\mathrm{NO}}$, and MDA-dG adducts. We specified generalized linear models (GLMs) (19) to investigate the relationship between each outcome and living in Sarroch versus Burcei, adjusting for relevant confounders. The details of each GLM fitted to each response variable are reported. All the analyses were stratified by the presence or absence of the history of respiratory symptoms.

Wheezing Symptoms. We investigated the relationship between wheezing symptoms in the last 12 months, as binary variable, and living in Sarroch versus Burcei. To account for differences in the characteristics of children living in the two areas, we adjusted for the following variables: age, gender, parental history of asthma, parental education, passive smoking, and damp or mold in child's bedroom. We reported the estimated logistic regression model coefficients as prevalence ratios (20).

$F E_{N O}$. Some $\mathrm{FE}_{\mathrm{NO}}$ measurement values (21/141: 14.9\%) were below the limit of instrument detection of $5 \mathrm{ppb}$. We considered these values as left censored and specified a Tobit regression model (21). We used the natural logarithm of $\mathrm{FE}_{\mathrm{NO}}$ as response and adjusted for age, gender, active and passive smoking, parental education, traffic intensity in the area of residence, respiratory infections in the last week, and history of prescription of inhaled steroids in the last 12 months. Estimated model coefficients were reported as percent variation in $\mathrm{FE}_{\mathrm{NO}}$ concentration for children living in Sarroch versus those living in Burcei. The influence of the presence of rhinoconjunctivitis symptoms [a proxy of an atopic condition (22)] on the response was evaluated in a sensitivity analysis.

Lung Function Indexes. As $\mathrm{FEV}_{1}$ and $\mathrm{FEF}_{25-75}$ distributions appeared positively skewed, we fitted a GLM for continuous gamma-distributed response and log link. All models were adjusted for age, gender, weight, height, active and passive smoking, parental education, damp or mold in child's bedroom, traffic intensity in the area of residence, respiratory infections in the last week, and history of prescription of inhaled steroids in the last 12 months. We report estimated model coefficients as percent variation in $\mathrm{FEV}_{1}$ and $\mathrm{FEF}_{25-75}$ for the children living in Sarroch versus those living in Burcei.

MDA-dG Adducts. We specified a GLM with log link and gamma-distributed response. The assumption is justified by the skewness of the empirical distribution of MDA$\mathrm{dG}$ adducts relative frequency. All models were adjusted for active and passive smoking, parental education, and history of prescription of inhaled steroids in the last 12 months. Estimated model coefficients were reported as percent variation in MDA-dG adducts for the children living in Sarroch versus those living in Burcei.

For each outcome, we checked the robustness of the results modifying the way in which model specification and adjustment for confounders were performed $(23,24)$. All statistical analyses were done using Stata 10.1 (25).

\section{RESULTS}

Questionnaires were completed by the parents of 275 children in Sarroch (response rate $=91.7 \%$ ) and the parents of 214 children in Burcei (response rate $=66.3 \%$ ). Characteristics of these children are shown in Table 1. Active smoking, as reported by the self-administered questionnaire, was present in $6.1 \%$ [90\% confidence interval $(\mathrm{CI})=2.4 ; 9.8]$ of adolescents living in Sarroch and in $16.7 \%$ (90\% CI $=10.9 ; 22.4)$ of those living in Burcei.

Prevalence of lifetime asthma was $6.2 \% \quad(90 \%$ $\mathrm{CI}=4.2 ; 9.1)$ in Sarroch and $6.5 \%(90 \% \mathrm{CI}=4.2 ; 10.0)$ in Burcei; prevalence of wheezing symptoms in the last 12 months was $12.0 \%(90 \% \mathrm{CI}=9.1 ; 15.6)$ and $6.5 \%(90 \%$ $\mathrm{CI}=4.2 ; 10.0)$, respectively. After adjusting for the set of potential confounding factors, the prevalence ratio of wheezing symptoms in the last 12 months for the children living in Sarroch versus those living in Burcei was 1.70 $(90 \% \mathrm{CI}=1.01 ; 2.86)$.

Twenty-seven children and adolescents with a history of asthma or wheezing symptoms in the last 12 months in Sarroch and 23 in Burcei, and 7 subjects without asthma or wheezing in Sarroch and 54 in Burcei were able to perform lung function. Descriptive statistics of $\mathrm{FEV}_{1}$ and of $\mathrm{FEF}_{25-75}$ are shown in Table 2: $\mathrm{FEV}_{1}$ and $\mathrm{FEF}_{25-75}$ 
TABLE 1.-Characteristics of study participants.

\begin{tabular}{lrr}
\hline Characteristic & Sarroch $(n=275)$ & Burcei $(n=214)$ \\
\hline Age, year (mean \pm SD) & $9.6 \pm 2.5$ & $9.6 \pm 2.5$ \\
Male sex, $n(\%)$ & $142(51.6)$ & $116(54.2)$ \\
Lifetime asthma, $n(\%)$ & $17(6.2)$ & $14(6.5)$ \\
Wheezing symptoms (last 12 months) & $33(12.0)$ & $14(6.5)$ \\
Rhinoconjunctivitis symptoms (last 12 months) & $19(6.9)$ & $13(6.1)$ \\
Children with prescription of inhaled steroids during the & $10(3.6)$ & $6(2.8)$ \\
$\quad$ last 12 months, $n(\%)$ & & \\
Parental history of asthma, $n(\%)$ & $23(8.4)$ & $3(1.4)$ \\
Parental schooling & & $43(20.1)$ \\
$\quad$ University, $n(\%)$ & $9(3.3)$ & $74(78.0)$ \\
$\quad$ High school $(13$ years), $n(\%)$ & $101(36.7)$ & $74.6)$ \\
$\quad<13$ years, $n(\%)$ & $162(58.9)$ & $25 / 201(12.4)$ \\
Parental smoking (current) & $130(47.3)$ & $30 / 201(14.9)$ \\
Damp or mold in child's bedroom & & $10 / 203(4.9)$ \\
$\quad$ Last 12 months, $n /$ total valid $(\%)$ & $42 / 255(16.5)$ & \\
First year of life, $n /$ total valid $(\%)$ & $37 / 255(14.5)$ & \\
Traffic intensity on street of residence (high) $n /$ total & $26 / 261(10.0)$ & \\
$\quad$ valid (\%) & & \\
\hline
\end{tabular}

TABLE 2.-Descriptive statistics of $\mathrm{FEV}_{1}, \mathrm{FEF}_{25-75}, \mathrm{FE}_{\mathrm{NO}}$, and MDA-dG DNA adducts in children and adolescents with asthma or wheezing and in those without, living in Sarroch and in the rural area of Burcei.

\begin{tabular}{|c|c|c|c|c|c|c|c|c|c|c|c|c|}
\hline & \multicolumn{6}{|c|}{ Sarroch } & \multicolumn{6}{|c|}{ Burcei } \\
\hline & $n$ & Min & $\mathrm{p} 50$ & Max & Mean & SD & $n$ & Min & $\mathrm{p} 50$ & Max & Mean & SD \\
\hline \multicolumn{13}{|c|}{ Subjects with asthma or wheezing } \\
\hline $\operatorname{FEV}_{1}(\mathrm{~L})^{\mathrm{a}}$ & 27 & 1.29 & 1.89 & 3.60 & 2.08 & 0.59 & 23 & 0.84 & 2.41 & 4.17 & 2.38 & 0.80 \\
\hline $\mathrm{FEF}_{25-75}(\mathrm{~L} / \mathrm{s})^{\mathrm{a}}$ & 27 & 0.96 & 2.18 & 4.05 & 2.16 & 0.76 & 23 & 0.55 & 2.89 & 4.73 & 2.64 & 1.11 \\
\hline $\mathrm{FE}_{\mathrm{NO}}(\mathrm{ppb})^{\mathrm{a}, \mathrm{b}}$ & 27 & 0 & 14 & 117 & 31.67 & 34.71 & 24 & 0 & 16.5 & 72 & 25.25 & 22.70 \\
\hline MDA-dG $\left(\right.$ RAL $\left.\times 10^{8}\right)$ & 8 & 15.80 & 29.35 & 133.47 & 45.04 & 42.61 & 14 & 3.80 & 28.12 & 115.60 & 34.16 & 29.56 \\
\hline \multicolumn{13}{|c|}{ Subjects without asthma or wheezing } \\
\hline $\mathrm{FEV}_{1}(\mathrm{~L})^{\mathrm{a}}$ & 7 & 1.42 & 2.08 & 3.56 & 2.32 & 0.79 & 54 & 1.58 & 2.42 & 4.50 & 2.46 & 0.64 \\
\hline $\mathrm{FEF}_{25-75}(\mathrm{~L} / \mathrm{s})^{\mathrm{a}}$ & 7 & 1.04 & 2.66 & 4.08 & 2.69 & 1.05 & 54 & 1.38 & 2.78 & 4.87 & 2.87 & 0.81 \\
\hline $\mathrm{FE}_{\mathrm{NO}}(\mathrm{ppb})^{\mathrm{a}, \mathrm{b}}$ & 8 & 5 & 8 & 48 & 13.25 & 14.29 & 55 & 0 & 8 & 50 & 8.96 & 9.21 \\
\hline MDA-dG $\left(\mathrm{RAL} \times 10^{8}\right)$ & 20 & 5.60 & 44.95 & 241.44 & 74.59 & 72.21 & 28 & 1.25 & 20.90 & 164.00 & 34.37 & 36.75 \\
\hline
\end{tabular}

Notes: ${ }^{\text {a }}$ The number of measurements are not always equal to the number of study participants due to invalid measurements.

${ }^{\mathrm{b}} \mathrm{FE}_{\mathrm{NO}}$ values not detected at the lowest value detectable $(5 \mathrm{ppb})$ by the test procedure were set to 0 .

values tended to be lower in children and adolescents living in Sarroch as compared with those living in the rural area of Burcei. In the regression model, after adjusting for potential confounders, a lower lung function expressed as a variation in $\mathrm{FEV}_{1}[-10.3 \%(90 \% \mathrm{CI}=-15.0 ;-6.0)]$ and in $\mathrm{FEF}_{25-75}[-12.9 \%(90 \% \mathrm{CI}=-20.7 ;-4.3)]$ was found for the subjects living in Sarroch as compared with those living in Burcei.

Measurements of $\mathrm{FE}_{\mathrm{NO}}$ were available for 27 children and adolescents with asthma or wheezing in the last 12 months in Sarroch, and for 24 in Burcei, and for 8 subjects without asthma or wheezing symptoms in Sarroch and 55 in Burcei. After adjusting for potential confounders, higher levels of $\mathrm{FE}_{\mathrm{NO}}[+35.0 \%(90 \% \mathrm{CI}=11.7 ; 80.1)]$ were found the for children and adolescents living in Sarroch as compared with those living in Burcei.

MDA-dG adduct values tended to be higher among the children living in Sarroch as compared with those living in the rural area of Burcei (Table 2). After adjusting for potential confounders, we found an increase in MDA-dG adducts $[+83.5 \%(90 \% \mathrm{CI}=22.9 ; 174.1)]$ in children living in Sarroch as compared with those living in Burcei.

Air pollutants concentrations are shown in Table 3. During the study period, we documented two episodes of Saharan dust storm with $\mathrm{PM}_{10}$ daily average concentrations above $60 \mu \mathrm{g} / \mathrm{m}^{3}$ at both sites. Over the remaining 12 days of measurements, the mobile station in Burcei recorded an average of $24.5 \mu \mathrm{g} / \mathrm{m}^{3}$, not very different from that of $23.0 \mu \mathrm{g} / \mathrm{m}^{3}$ recorded in Sarroch.

\section{DISCUSSION}

In this cross-sectional study, we found a decrease in lung function and increased markers of bronchial inflammation and oxidative DNA damage in children living near an oil refinery as compared with those living in a control nonpolluted area. Asthma symptoms in the last 12 months were also different in the two areas. The associations between wheezing symptoms, lung function, airways markers of 
TABLE 3.-Weekly averages of air pollutants in Sarroch (21 sampling locations) and in Burcei (2 sampling locations).

\begin{tabular}{lcccr}
\hline & \multicolumn{4}{c}{ Concentrations of air pollutants $\left(\mu \mathrm{g} / \mathrm{m}^{3}\right)$} \\
\cline { 2 - 5 } & Minimum & Median & Mean & Maximum \\
\hline SO2 & & & & \\
Sarroch & 6.9 & 12.4 & 18.1 & 61.6 \\
$\quad$ Burcei & 0.3 & 3.4 & 3.6 & 7.6 \\
NO2 & & & & \\
Sarroch & 5.2 & 14.1 & 15.6 & 28.7 \\
Burcei & 1.7 & 3.6 & 3.6 & 5.3 \\
Benzene & 1.8 & 3.7 & 3.7 & 9.0 \\
Sarroch & 1.3 & 1.4 & 1.4 & 1.5 \\
Burcei & & & & 135.3 \\
Ozone & 108.6 & 127.7 & 124.8 & 149.0 \\
$\quad$ Sarroch & 127.0 & 135.8 & 136.9 & \\
Burcei & & & & \\
\hline
\end{tabular}

inflammation and oxidative stress, and area of residence remained after controlling for confounding.

In the Sarroch municipality, since 1965, a big highcomplexity refinery and a large liquid fuel gasification plant are located. High levels of $\mathrm{SO}_{2}$ and $\mathrm{PM}_{10}$ were documented even in recent years (10). Total annual emissions of $\mathrm{SO}_{2}$ sum up to more than 8000 ton and total particles to more than 500 ton.

As the populations of Sarroch and Burcei experienced different environmental conditions over years, long-term effects of pollutants are more likely to explain our findings; however, as lung function, markers of inflammation and oxidative stress, and weekly air pollutant concentrations were measured concurrently at the two municipalities, we cannot exclude a short-term effect.

For all the outcomes studied, we documented the effects both in children with a history of asthma or wheezing and in those without. Our findings are therefore consistent with recent studies showing that adverse health outcomes of air pollution are present also in healthy children $(26,27)$.

The relative deficit in $\mathrm{FEV}_{1}$ for the subjects living in Sarroch $(-10.3 \%)$ was similar to that found for passive smoking $(-6.8 \%$ for children exposed to passive smoking vs. not exposed) and was of the same order of magnitude of that reported in longitudinal studies on the long-term consequences of air pollution (1).

Confounder-adjusted average concentrations of $\mathrm{FE}_{\mathrm{NO}}$ in exhaled breath were $13.48 \mathrm{ppb}$ in children residing in the polluted area and $9.98 \mathrm{ppb}$ in children residing in the rural area. $\mathrm{FE}_{\mathrm{NO}}$ has been related to the exposure to particles, $\mathrm{NO}_{2}$ and ozone, measured either by personal or by ambient monitors in panel studies of children with asthma and in healthy children $(6,28,29)$. Moreover, $\mathrm{FE}_{\mathrm{NO}}$ levels have been found to be elevated in the children living in areas characterized by high traffic exposure $(30,31)$.

Confounder-adjusted average levels of MDA-dG adducts in nasal mucosal cells were $65.8 \mathrm{RAL} \times 10^{8}$ in Sarroch versus 35.8 RAL $\times 10^{8}$ in the rural area of Burcei, comparable with those detected in various adult human tissues (8). Nasal mucosa cells are the first site of contact of the respiratory tract with the mixtures of airborne substances present in the environment and constitute therefore the first line of defense against various xenobiotics. Nasal epithelium is an accessible and easyto-monitor tissue. A number of studies have shown that biomarkers of oxidative DNA damage are high in biological media, most commonly urine and blood, of adults exposed to air pollution, in particular particulate matter and benzene (32). An increment has also been found in the leucocytes, urine cells, and nasal mucosa cells of schoolchildren living in metropolitan areas, such as Bangkok (Thailand) (33) and Mexico City (34), and in the urine cells of children living near power plants in Taichung, Taiwan (35).

Although the overall picture arising from our data is consistent with a role of environmental pollutants on lung function and inflammation, this study has some limitations.

Questionnaire response rate was lower in the rural municipality of Burcei than in Sarroch; however, if a selection bias occurred in Burcei, this was probably in a conservative direction, that is, inclusion of children and adolescents with respiratory problems rather than the opposite. On the contrary, the higher participation rate in Sarroch could have been partially due to a concern on the possible effect of pollution on respiratory health; this could have also affected the reporting of wheezing symptoms by the parents of the studied children. These considerations, together with the fact that questionnaire surveys were conducted in different seasons in the two areas, suggest to regard the relationship between wheezing symptoms in the last 12 months and area of residence as only an association.

This study is inherently ecological in nature, comparing two populations at different baseline levels of pollution. We adjusted for a series of known risk factors and disease markers, but we cannot exclude the potential role of underlying unmeasured population characteristics, among those genetically susceptible. However, the Sardinian population is a very homogeneous founder 
population which evolved from a few initial inhabitants without appreciable in-migration (36).

This study was cross-sectional; exposure and outcome were assessed concurrently. Change of residence was investigated by specific items in the parental questionnaire; in Sarroch $58.2 \%$ of children lived in the same house since birth, whereas in Burcei the percentage raised to $74.2 \%$. In a sensitivity analysis, we controlled all models by change of residence, and the results were not modified.

Exposure characterization was limited to a short period during the measurements campaign. The information on particles $\left(\mathrm{PM}_{10}\right)$ was scarce due to two episodes of Saharan dust storm during the campaign. These episodes, whose occurrence is well documented in the Mediterranean area (37), were identified looking at the hourly concentration patterns and the correlation with similar pattern at urban and rural stations. Yet, for the area of Sarroch, we have information on $\mathrm{PM}_{10}$ for the whole period January-June 2007 from the Environmental Protection Agency Air Quality Network. The mean daily average and the maximum value registered for $\mathrm{PM}_{10}$ during that period were $22.57 \mu \mathrm{g} / \mathrm{m}^{3}$ and $64.11 \mu \mathrm{g} / \mathrm{m}^{3}$, respectively. In the same period, hourly series of $\mathrm{PM}_{10}$ showed maximum values during the night (after $8.00 \mathrm{pm}$ till midnight), coherent with an industrial source of pollution rather than with car traffic. On the contrary, children living in Burcei, a small rural municipality $648 \mathrm{~m}$ above sea level, and without industrial settlements, are probably exposed to low levels of particulates.

In our study, we did not undertake laboratory examinations for atopy. The knowledge of atopic status could be relevant in term of effects of air pollution on atopic diseases (38) and relevant for the increase in $\mathrm{FE}_{\mathrm{NO}}$ levels (5). The combination of the two ISAAC questions on rhinitis (rhinitis symptoms accompanied by itchy, watery eyes) has been suggested as a useful epidemiological instrument to measure the occurrence of allergic rhinitis (22). In our study, prevalence of rhinoconjunctivitis (last 12 months) was similar in Sarroch and in the rural area of Burcei: $6.9 \%$ versus $6.1 \%$. Children and adolescents with rhinoconjunctivitis, in comparison with those without, had average $\mathrm{FE}_{\mathrm{NO}}$ levels of $40.2 \mathrm{ppb}$ versus $13.8 \mathrm{ppb}$ in Sarroch and $31.8 \mathrm{ppb}$ versus $11.3 \mathrm{ppb}$ in Burcei; this confirms the previous studies that showed that atopy is a cofactor of $\mathrm{FE}_{\mathrm{NO}}$ variation (5). On the contrary, the fact that we did not find any significant interaction between our exposure-city indicator and the symptoms suggestive of atopy, together with the similar prevalence of rhinoconjunctivitis symptoms in the two communities, is reassuring.

\section{CONCLUSIONS}

We found lower lung function and higher levels of markers of inflammation and oxidative stress $\left(\mathrm{FE}_{\mathrm{NO}}\right.$ and MDA-dG adducts) in the children living in an industrial polluted area in comparison with those found in the children living in a rural nearby area. Although these findings were obtained in two small population samples, they seem to add evidence to the recent studies $(39,40)$, showing an excess of asthma and respiratory symptoms and a decrease in lung function in children living in proximity of petroleum refineries, and to the previous studies conducted in areas with outdoor air pollutants-mainly $\mathrm{SO}_{2}$ but also particulates-derived from industrial processes $(41,42)$.

We confirm that measurements of biomarkers produced in the airways could be useful, noninvasive tools in epidemiological studies on the health effect of air pollution in children and that oxidative stress could be a major feature underlying the toxic effects of air pollutants (3).

\section{ACKNOWLEDGMENTS}

This study was financed by the Municipality of Sarroch; the Ministry of Welfare, project RF-SAR-2006-387926, and the Ministry of Education, University and Scientific Research, projects 2006131039 and 2007252HT8.

\section{REFERENCES}

1. Götschi T, Heinrich J, Sunyer J, and Künzli N. Long-term effects of ambient air pollution on lung function: a review. Epidemiology 2008; 19:690-701.

2. Churg A, Brauer M, del Carmen Avila-Casado M, Fortoul TI, and Wright JL. Chronic exposure to high levels of particulate air pollution and small airway remodelling. Environ Health Perspect 2003; 111:714-718.

3. Kelly FJ. Oxidative stress: its role in air pollution and adverse health effects. Occup Environ Med 2003; 60:612-616.

4. Ciencewicki J, Trivedi S, Kleeberger S R. Oxidants and the pathogenesis of lung diseases. J Allergy Clin Immunol 2008; 122:456-468.

5. Pijnenburg MW, De Jongste JC. Exhaled nitric oxide in childhood asthma: a review. Clin Exp Allergy 2007; 38:246-259.

6. Delfino RJ, Staimer N, Gillen D, Tjoa T, Sioutas C, Fung K, George $\mathrm{SC}$, and Kleinman MT. Personal and ambient air pollution is associated with increased exhaled nitric oxide in children with asthma. Environ Health Perspect 2006; 114:1736-1743.

7. Romieu I, Barraza-Villarreal A, Escamilla-Nuñez C, Almstrand AC, Diaz-Sanchez D, Sly PD, and Olin AC. Exhaled breath malondialdehyde as a marker of effect of exposure to air pollution in children with asthma. J Allergy Clin Immunol 2008; 121:903-909.

8. De Bont R, van Larebeke N. Endogenous DNA damage in humans: a review of quantitative data. Mutagenesis 2004; 19:169-185.

9. VanderVeen LA, Hashim MF, Shyr Y, and Marnett LJ. Induction of frame shift and base pair substitution mutations by the major DNA adduct of the endogenous carcinogen malondialdehyde. Proc Natl Acad Sci USA 2003; 100:14247-14252.

10. Regione autonoma della Sardegna. Relazione annuale sulla qualità dell'aria in Sardegna nel 2005 [in Italian]. Available at: http:// www.regione. sardegna.it $/ \mathrm{j} / \mathrm{v} / 25 ? \mathrm{~s}=34504 \& \mathrm{v}=2 \& \mathrm{c}=1260 \& \mathrm{t}=1$. Accessed October 29, 2009.

11. Pirastu R, Bellu C, Greco P, Pelosi U, Pistelli R, Accetta G, and Biggeri A. Indoor exposure to environmental tobacco smoke and dampness: respiratory symptoms in Sardinian children-DRIAS study. Environ Res 2009; 109:59-65.

12. The International Study of Asthma and Allergies in Childhood (ISAAC). Phase One Manual. 2nd ed. Auckland, New Zealand/ Münster, Germany: ISAAC, 1993. Available at: http://isaac.auckland. ac.nz. Accessed October 29, 2009.

13. Galassi C, Forastiere F, Biggeri A, Gabellini C, De Sario M, Ciccone G, Biocca M, Bisanti L, and Gruppo Collaborativo SIDRIA 2. 
SIDRIA second phase: objectives, study design and methods. Epidemiol Prev 2005; 29:9-13.

14. ATS/ERS recommendations for standardised procedures for the online and offline measurement of exhaled lower respiratory nitric oxide and nasal nitric oxide, 2005. Am J Respir Crit Care Med 2005; 171: 912-930.

15. Miller MR, Hankinson J, Brusasco V, Burgos F, Casaburi R, Coates A, Crapo R, Enright P, van der Grinten CP, Gustafsson P, Jensen R, Johnson DC, MacIntyre N, McKay R, Navajas D, Pedersen OF, Pellegrino R, Viegi G, and Wanger J; ATS/ERS Task Force. Standardization of spirometry. Eur Respir J 2005; 26:319-338.

16. van Helden YGJ, Keijer J, Hell SG, Picó C, Palou A, Oliver P, Munnia A, Briedé JJ, Peluso M, Franssen-van Hal NL, van Schooten FJ, and Godschalk RW. Beta-carotene affects oxidative stress related DNA damage in lung epithelial cells and in ferret lung. Carcinogenesis 2009; 30(12):2070-2076.

17. European Committee for Standardization. Ambient air qualityDiffusive samplers for the determination of concentrations of gases and vapours-Requirements and test methods-Part 2: specific requirements and test methods, EN 13528-2, Brussels, 2002.

18. Biggeri A, Baccini M, Bellini P, and Terracini P. Meta-analysis of the Italian Studies on Short-term Effects of Air Pollution (MISA), 1990 1999. Int J Occup Environ Health 2005; 11:107-122.

19. McCullagh P, Nelder JA. Generalized Linear Models. 2nd ed. London: Chapman and Hall/CRC Press Publisher, 1989.

20. Zocchetti C, Consonni D, Bertazzi PA. Estimation of prevalence rate ratios from cross-sectional data. Int J Epidemiol 1995; 24:1064-1067.

21. Tobin J. Estimation of relationships for limited dependent variables. Econometrica 1958; 26:24-36.

22. Weinmayr G, Forastiere F, Weiland SK, Rzehak P, Abramidze T, Annesi-Maesano I, Björkstén B, Brunekreef B, Büchele G, Cookson WO, von Mutius E, Pistelli R, and Strachan DP; ISAAC Phase Two Study Group. International variation in prevalence of rhinitis and its relationship with sensitisation to perennial and seasonal allergens. Eur Respir J 2008; 32:1250-1261.

23. Rosenbaum PR, Rubin DB. The central role of the propensity score in observational studies for causal effects. Biometrika 1983; 70:41-55.

24. Becker SO, Ichino A. Estimation of average treatment effects based on propensity scores. The Stata Journal 2002; 2:358-377.

25. Stata Corporation. STATA Statistical Software: Release 10.1 Special Edition. College Station, TX: Stata Corporation, 2007.

-26. Gauderman WJ, Avol E, Gilliland F, Vora H, Thomas D, Berhane K, McConnell R, Kuenzli N, Lurmann F, Rappaport E, Margolis H, Bates D, and Peters J. The effect of air pollution on lung development from 10 to 18 years of age. N Engl J Med 2004; 351:1057-1067.

27. Kulkarni N, Pierse N, Rushton L, and Grigg J. Carbon in airway macrophages and lung function in children. N Engl J Med 2006; 355:21-30.

28. Koenig JQ, Jansen K, Mar TF, Lumley T, Kaufman J, Trenga CA, Sullivan J, Liu LJ, Shapiro GG, and Larson TV. Measurement of offline exhaled nitric oxide in a study of community exposure to air pollution. Environ Health Perspect 2003; 111:1625-1629.

29. Nickmilder M, de Burbure C, Carbonnelle S, Dumont X, Bernard A, and Derouane A. Increase of exhaled nitric oxide in children exposed to low levels of ambient ozone. J Toxicol Environ Health 2007; 70: 270-274.

30. Dales R, Wheeler A, Mahmud M, Frescura AM, Smith-Doiron M, Nethery E, and Liu L. The influence of living near roadways on spirometry and exhaled nitric oxide in elementary schoolchildren. Environ Health Perspect 2008; 116:1423-1427.

31. Holguin F, Flores S, Ross Z, Cortez M, Molina M, Molina L, Rincon C, Jerrett M, Berhane K, Granados A, and Romieu I. Traffic-related exposures, airway function, inflammation, and respiratory symptoms in children. Am J Respir Crit Care Med. 2007; 176:1236-1242.

32. Sørensen M, Autrup H, Møller P, Hertel O, Jensen SS, Vinzents P, Knudsen LE, and Loft S. Linking exposure to environmental pollutants with biological effects. Mutat Res 2003; 544: 255-271.

33. Buthbumrung N, Mahidol C, Navasumrit P, Promvijit J, Hunsonti P, Autrup H, and Ruchirawat M. Oxidative DNA damage and influence of genetic polymorphisms among urban and rural schoolchildren exposed to benzene. Chem Biol Interact 2008; 172:185-194.

34. Calderón-Garcidueñas L, Wen-Wang L, Zhang YJ, Rodriguez-Alcaraz A, Osnaya N, Villarreal-Calderón A, and Santella RM. 8-hydroxy2'-deoxyguanosine, a major mutagenic oxidative DNA lesion, and DNA strand breaks in nasal respiratory epithelium of schoolchildren exposed to urban pollution. Environ Health Perspect 1999; 107: 469-474.

35. Wong RH, Kuo CY, Hsu ML, Wang TY, Chang PI, Wu TH, and Huang S. Increased levels of 8-hydroxy-2'-deoxyguanosine attributable to carcinogenic metal exposure among schoolchildren. Environ Health Perspect 2005; 113:1386-1390.

36. Balaci L, Spada MC, Olla N, Sole G, Loddo L, Anedda F, Naitza S, Zuncheddu MA, Maschio A, Altea D, Uda M, Pilia S, Sanna S, Masala M, Crisponi L, Fattori M, Devoto M, Doratiotto S, Rassu S, Mereu S, Giua E, Cadeddu NG, Atzeni R, Pelosi U, Corrias A, Perra R, Torrazza PL, Pirina P, Ginesu F, Marcias S, Schintu MG, Del Giacco GS, Manconi PE, Malerba G, Bisognin A, Trabetti E, Boner A, Pescollderungg L, Pignatti PF, Schlessinger D, Cao A, and Pilia G. IRAK-M is involved in the pathogenesis of early-onset persistent asthma. Am J Hum Genet 2005; 80:1103-1114.

37. Barkan J, Alpert P, Kutiel H, and Kishcha P. Synoptics of dust transportation days from Africa toward Italy and central Europe. J Geophys Res 2005; 110:D07208, doi: 10.1029/2004JD005222.

-38. Morgenstern V, Zutavern A, Cyrys J, Brockow I, Koletzko S, Krämer U, Behrendt $\mathrm{H}$, Herbarth $\mathrm{O}$, von Berg A, Bauer CP, Wichmann HE, and Heinrich J; GINI Study Group; LISA Study Group. Atopic diseases, allergic sensitization, and exposure to traffic-related air pollution in children. Am J Respir Crit Care Med 2008; 177: 1331-1337.

39. Smargiassi A, Kosatsky T, Hicks J, Plante C, Armstrong B, Villeneuve PJ, and Goudreau S. Risk of asthmatic episodes in children exposed to sulphur dioxide stack emissions from a refinery point source in Montreal, Canada. Environ Health Perspect 2009; 117:653-659.

40. Wichmann FA, Müller A, Busi LE, Cianni N, Massolo L, Schlink U, Porta A, and Sly PD. Increased asthma and respiratory symptoms in children exposed to petrochemical pollution. J Allergy Clin Immunol 2009; 123:632-638.

41. Forastiere F, Corbo GM, Pistelli R, Michelozzi P, Agabiti N, Brancato G, Ciappi G, and Perucci CA. Bronchial responsiveness in children living in areas with different air pollution levels. Arch Environ Health 1994; 49:111-118.

42. Aekplakorn W, Loomis D, Vichit-Vadakan N, Shy C, Wongtim S, and Vitayanon P. Acute effect of sulphur dioxide from a power plant on pulmonary function of children, Thailand. Int J Epidemiol 2003; 32:854-861. 